\title{
The genus Piper (Piperaceae) in the Mata das Flores State Park, Espírito Santo, Brazil ${ }^{1}$
}

\author{
Jheniffer Abeldt Christ ${ }^{2,4,6}$, Valderes Bento Sarnaglia-Junior ${ }^{3}$, Lucas Mesquita Barreto ${ }^{2,4}$, \\ Elsie Franklin Guimarães ${ }^{3}$, Mário Luís Garbin ${ }^{5}$ \& Tatiana Tavares Carrijo ${ }^{2,4}$
}

\begin{abstract}
The conservation and management of the Atlantic Forest depends upon reliable knowledge about how many and which species this biome shelters. Floristic inventories have an important role in this process, especially when conducted in poorly known remnants, with a high conservation priority. This paper presents the study of the genus Piper (Piperaceae) in the Mata das Flores State Park, Castelo municipality, Espírito Santo state (ES). The study was based on the analysis of dried specimens, as well as those observed in the field, from February 2012 to August 2015. Twenty species of piper were identified. Amongst these species, Piper dilatatum, P. macedoi and $P$. piliovarium were recorded for the first time for the Espírito Santo state. Piper bicorne, an endemic species from ES and known only for the Santa Leopoldina municipality, had its geographical distribution expanded to the Castelo municipality. Most of the Piper species in the MFSP occur in valleys, and they are commonly found near watercourses. This is worrying given that these areas are just the most affected by the expansion of the rural and urban areas that surround the Park.
\end{abstract}

Key words: Atlantic Forest, flora, taxonomy.

\begin{abstract}
Resumo
A conservação e o manejo da Floresta Atlântica dependem de conhecimento confiável sobre quantas e quais espécies este bioma abriga. Inventários florísticos têm um importante papel neste processo, especialmente quando conduzidos em remanescentes pouco conhecidos com alta prioridade de conservação. Este trabalho apresenta o estudo realizado no gênero Piper (Piperaceae) no Parque Estadual de Mata das Flores, município de Castelo, estado do Espírito Santo (ES). O estudo foi baseado na análise de espécimes herborizados, assim como observados a campo, em expedições realizadas de fevereiro de 2012 a agosto de 2015. Vinte espécies de Piper foram identificadas. Destas, Piper dilatatum, P. macedoi e P. piliovarium foram registradas pela primeira vez para o estado do Espírito Santo. Piper bicorne, espécie endêmica do ES e conhecida apenas para o Município de Santa Leopoldina, teve a sua distribuição geográfica expandida para o Município de Castelo. A maior parte das espécies de Piper no PEMF ocorre nas áreas de vale, e frequentemente próximas a cursos d'água. Tal fato gera preocupação em relação à conservação destas espécies, dado que estas áreas são justamente as mais afetadas pela expansão das áreas urbana e rural do entorno.

Palavras-chave: Floresta Atlântica, flora, taxonomia.
\end{abstract}

\section{Introduction}

Piperaceae is a basal angiosperm family that comprises about 3,615 species easily recognized by the branches with well-marked nodes, simple and alternate leaves, and small flowers grouped in spikes. The genera that occur in Brazil (Manekia, Peperomia and Piper) can be easily distinguished by habit. Manekia comprises climbing vines (Monteiro \& Guimarães 2009), Peperomia comprises herbaceous (terrestrial or epiphytic) species (Monteiro \& Guimarães 2008), while Piper includes tree and shrub species (Monteiro \& Guimarães 2009).

\footnotetext{
'Part of the first author Master's thesis.

${ }^{2}$ Universidade Federal do Espírito Santo/CCA, Lab. Botânica, Alto Universitário s/n, Guararema, 29500-000, Alegre, ES, Brasil.

${ }^{3}$ Instituto de Pesquisas Jardim Botânico do Rio de Janeiro, R. Pacheco Leão 915, Jardim Botânico, 22460-030, Rio de Janeiro, RJ, Brasil.

${ }^{4}$ Universidade Federal do Espírito Santo/CCA, Prog. Pós-graduação em Genética e Melhoramento, CCA-UFES, Alto Universitário s/n, Guararema, 29500-000, Alegre, ES, Brasil.

${ }^{5}$ Universidade Vila Velha, Prog. Pós-graduação em Ecologia de Ecossistemas, R. Comissário José Dantas de Melo s/n, Boa Vista, 29102770, Vila Velha, ES, Brasil.

${ }^{6}$ Author for correspondence: jhenifferabeldt@gmail.com
} 
The first contribution to the knowledge of Piperaceae in Brazil was the classic study of Miquel (1832) in the "Flora Brasiliensis". However, Yuncker $(1972,1973,1974)$ provided the first comprehensive taxonomic monograph for the family in the country. This knowledge was organized in five monographs containing morphological descriptions, data about species geographical distribution, ecological aspects, taxonomic information, and identification keys. For 50 years, he collected information about 457 species of Piperaceae. This is the most important contribution to the taxonomy of Piperaceae in Brazil given that no similar contribution with the same comprehensiveness was provided later. Moreover, regional floras played an important role in broadening our understanding about Piperaceae, and revealing new species (e.g., Carvalho-Silva et al. 2015; Sarnaglia-Junior 2015).

Considering the South and Southeast regions of Brazil, the states of Minas Gerais, Rio de Janeiro, São Paulo and Santa Catarina are those with the largest number of taxonomic studies in Piperaceae (e.g., Carvalho-Okano \& Alves 1998; Guimarães \& Valente 2001; Guimarães \& Monteiro 2006; Medeiros \& Guimarães 2007; Bardelli et al. 2008; Monteiro \& Guimarães 2008; Carvalho-Silva \& Guimarães 2009; Monteiro \& Guimarães 2009; Monteiro 2013; Carvalho-Silva et al. 2013). Most of these studies were made as part of floristic inventories within conservation units. Only the states of São Paulo and Santa Catarina have comprehensive surveys for Piperaceae species (Guimarães \& Valente 2001; Guimarães \& Carvalho-Silva 2012). Based on updated knowledge, Piperaceae comprise now 458 in Brazil (BFG 2015). The highest amount of species is currently registered in the southeast region (261), followed by the North (239), Northeast (147), south (132), and Midwest (112) regions (BFG 2015).

In the southeast region, the Rio de Janeiro state leads the ranking of species number with 183 taxa, followed by Minas Gerais with 164 species, São Paulo with 157 species, and Espírito Santo with 130 species (BFG 2015). Even though the states of Espírito Santo and Rio de Janeiro have similar areas (46,077.519 $\mathrm{km}^{2}$ and 43,696.054 $\mathrm{km}^{2}$, respectively), the former shelters $58 \%$ of all species present in the latter (BFG 2015). This difference in species richness is probably due, partly, to the presence of collection gaps in Espírito Santo.

The scenario of gap collections is worrying considering the increasing loss of vegetation cover in Espírito Santo state due to decades of agricultural and industrial activities, and the extraction of marble and granite (Paula 2006). Consequently, the current vegetation cover of the state is comprised by remnants of different sizes, and this is a small-scale example of the fragmentation of the Atlantic Forest as a whole (Ribeiro et al. 2009). Such fragmentation along with a lack of floristic richness data, severely limits the execution of ecological studies. Given these issues, this study was conducted in a Conservation Unit called Mata das Flores State Park (MFSP). The area in which the MFSP is located is of high priority for conservation (Instituto de Pesquisas da Mata Atlântica 2011). Here we present a floristic study of the genus Piper.

\section{Material and Methods}

Study site and fieldwork

This study was carried out in the Mata das Flores State Park. This conservation unit is adjacent to the urban area of the Castelo municipality, Espírito Santo (Fig. 1, 20³5'54'S; 41¹0'53'W), and comprises one of the last remnants of Atlantic Forest in Southern Espírito Santo (IEMA 2014). The vegetation is classified as a lowland tropical rainforest (Oliveira-Filho 2005), with elevation ranging from $100-440 \mathrm{~m}$ asl. The total area of the MFSP comprises 800 ha divided in three forest fragments surrounded by livestock activities and plantations of Coffea canephora L. Other impacts to the vegetation of this Conservation Unit were the opening of roads for vehicle traffic, and trails for motocross practice in the past. The field expeditions for collection and observation of individuals were conducted from February 2012 to August 2015, with a periodicity of at least one daily excursion per month. The fertile samples were photographed, dried following the usual procedures for taxonomic studies (Peixoto et al. 2002), and included in VIES and RB herbaria (acronyms according to Thiers, continuously updated).

\section{Taxonomic study}

Specimens collected were identified based on specialized bibliographies for Piperaceae (Miquel 1832; Yuncker 1972, 1973, 1974) and, when necessary, images of nomenclatural types available in virtual sites were consulted (e.g., Tropics, Global Plants, Reflora). Infraspecific levels were not considered here. The terms of morphological descriptions followed the concepts and terminology of Hickey \& King (2000) and Radford et al. (1974). Measures were made on long or wide portions of the vegetative and reproductive structures. Taxonomic literature is according to Lawrence et al. (1968) and Stafleu \& Cowan (1979). Name abbreviations for authors follow Brummit \& Powell (1992). 

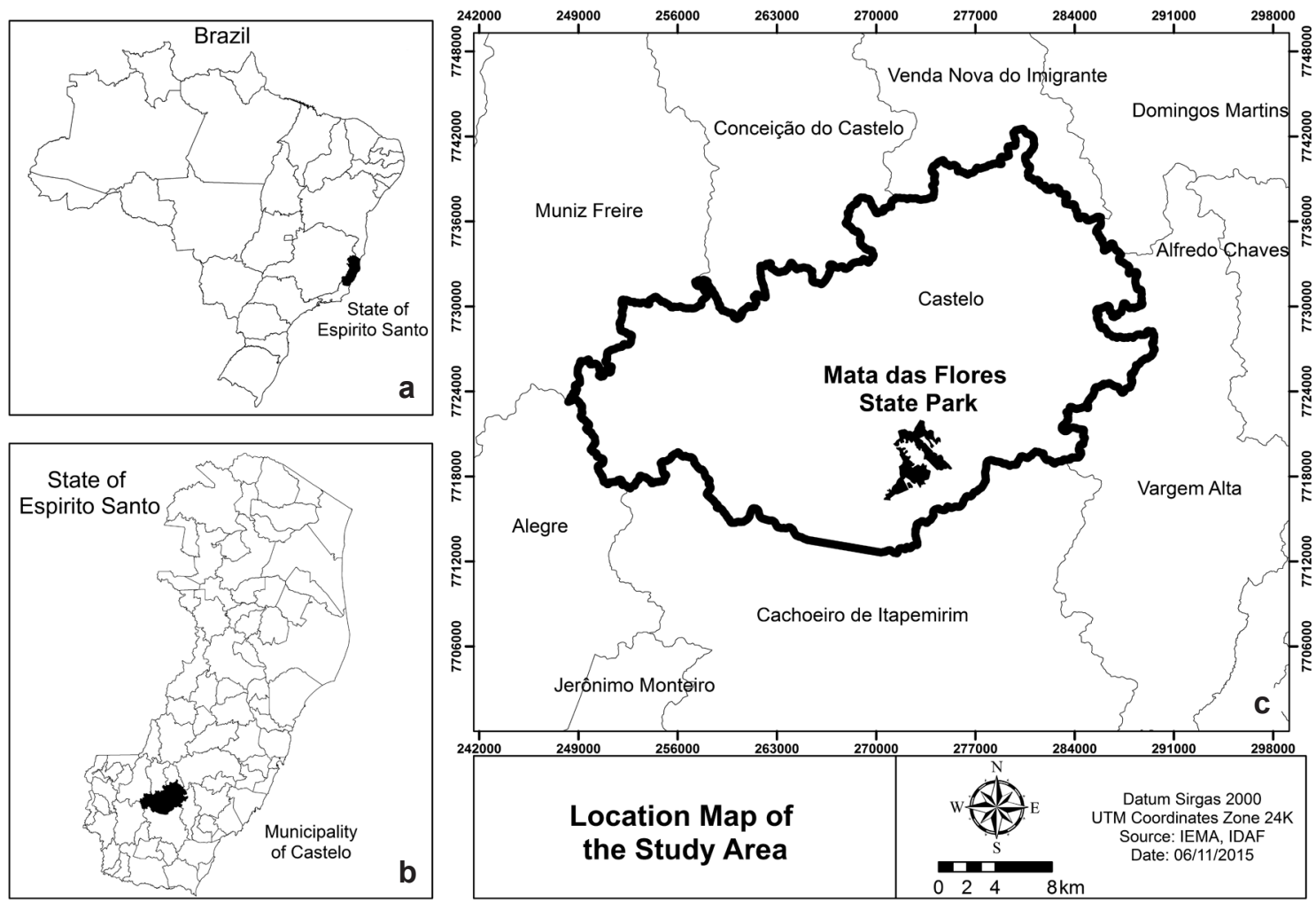

Figure 1 - Location map of the study area - a. Brazil map highlighting the Espírito Santo state; b. Espírito Santo state highlighting the municipality of Castelo; c. municipality of Castelo highlighting the studied area (MFSP).

\section{Results and Discussion}

Twenty species occurs of Piper in MFSP. Vegetative characters, such as leaf blade asymmetric, venation pattern and pilosity of branches were useful in species identification. The most informative reproductive characters is the position of the spike, especially useful to delimit very similar species based on vegetative characters.

Piper dilatatum, P. macedoi and P. piliovarium are new records for ES. The detection of these new records after the last update of the Brazilian Flora Plant List in 2015, indicates that floristic inventories are still necessary to raise the knowledge of the species richness, especially in areas with collection gaps as de South of ES.

Most of Piper species in MFSP occur near from watercourses in the understory, or in disturbed areas of roadsides. Considering this, strategies for the conservation of Piper species in this Conservation Unit must necessarily consider the protection of lowland areas, which are daily affected by the surrounding urban and rural areas expansion.

Considering that the floristic composition of the Atlantic Forest remnants is a strong indicator of their conservation status, our results with Piper reveals that even small fragments may have high species richness.

\section{Key to the species of Piper from the Mata das Flores State Park}

1. Leaf blade with campilodromous venation; spike arranged in umbels

19. Piper umbelatum

1'. Leaf blade with other type of venation; spike solitary

2. Flower and fruit pedicellate

2'. Flower and fruit not pedicellate

3. Branches pubescent; leaf blade with apex acute to acuminate

3'. Branches pilose; leaf blade with apex attenuate 
4. Leaf blade with acrodomous venation

4'. Leaf blade with eucamptodromous or camptodromous venation

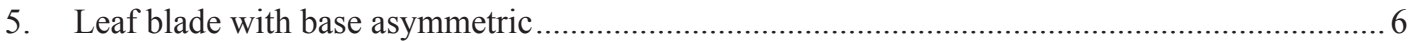

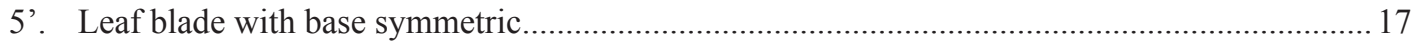

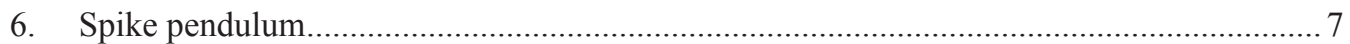

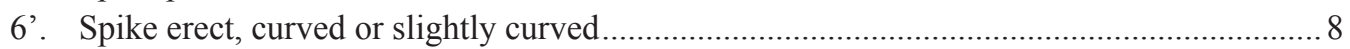

7. Branches internodes larger than $6.5 \mathrm{~cm}$ long; spike larger than $15 \mathrm{~cm}$ long; floral bract glabrous

8. Piper cernuum

7'. Branches internodes less than $6.5 \mathrm{~cm}$ long; spike less than $15 \mathrm{~cm}$ long; floral bract pubescent.

7. Piper caldense

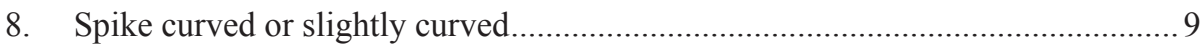

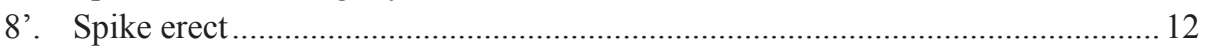

9. Leaf blade glabrous or puberulous; floral bract round ................................ 10

9'. Leaf blade scabrous; floral bract triangular................................................ 11

10. Leaf blade with apex attenuated; peduncle puberulous.

9. Piper dilatatum

10'. Leaf blade with acute apex acuminate; peduncle glabrous

11. Piper glabratum

11. Leaf blade with 7 pairs of secondary veins; secondary venation anastomosed at the margin; stigma ligulate.

1. Piper aduncum

11'. Leaf blade with 5 pairs of secondary veins; secondary venation not anastomosed at the margin; stigma filiform

10. Piper gaudichaudianum

12. Branches glabrous; leaf blade with base asymmetry larger than $8 \mathrm{~mm}$

4. Piper arboreum

12 '. Branches glabrous or pilose; leaf base with asymmetry less than $8 \mathrm{~mm}$ 13

13. Petiole canaliculate; leaf blade base acute.................... 14

13'. Petiole striate, leaf blade base cordate or round ........... 16

14. Margin repandous

15. Piper permucronatum

14'. Margin entire 15

15. Branches pilose; 5-6 pairs of secondary veins

13. Piper macedoi

$15^{\prime}$. Branches glabrous; 8 pairs of secondary veins

20. Piper vicosanum

16. Leaf blade base of the cordate; venation not anastomosed at the margin; 4 stigmas

16. Piper piliovarium

16'. Leaf blade base of the round; venation anastomosed at the margin, 3 stigmas .....

18. Piper tuberculatum

17. Petiole striate; leaf blade base subcordate

17. Piper pubisubmarginalum

17'. Petiole canaliculate; leaf blade base acute or obtuse 
18. Venation camptodromous.

12. Piper hoffmannseggianum

18 '. Venation eucamptodromous.

19. Leaf blade with 4-pairs of arcuate secondary venation.

6. Piper bowiei

19'. 7 Leaf blade with 10 pairs of arcuate secondary veins ...

5. Piper bicorne

\section{Piper aduncum L.}

Fig. 2a-c

Shrub $3 \mathrm{~m}$ tall, branches pilose, without protrusions, internodes ranging from 4.9 to 7.7 $\mathrm{cm}$. Petiole striate, sheath short, 0.22 to 1.05 $\mathrm{cm}$ long, pilose, not overlapping the base of the leaf blade. Leaf blade symmetric, chartaceous, 13.1-22.3 × 3.5-6.5 cm, elliptic, ovate-elliptical, scabrous, base asymmetric, cordate, one size 2-6 $\mathrm{mm}$ shorter at the petiole, apex acute-acuminate, eucamptodromous venation, 7 pairs of secondary veins arcuate to the apex, arranged up to apex of the main vein, not prominent on the face abaxial, anastomosed on the margin, margin entire. Spike solitary, curved, $6.1-10.5 \mathrm{~cm}$ long, peduncle pilose. Flower not pedicellate, floral bract triangular, pubescent fimbriate, ovary glabrous, 4-stamens without glands, styles inconspicuous, 3-stigma, ligulate. Fruit not seen.

Selected specimens examined: 16.V.2013, fl., J.A. Christ et al. 03 (VIES); 15.I.2013, fl., T.T. Carrijo et al. 1583 (VIES); 15.I.2013, fl., T.T. Carrijo et al. 1561 (VIES); 29.X.2013, fl., J.A. Christ et al. 10 (VIES); 17.XI.2014, fl., J.A. Christ 87 (VIES); 21.VIII.2015, fl., J.A. Christ 95 (VIES); 21.VIII.2015, fl., J.A. Christ 96 (VIES); 21.VIII.2015, fl., J.A. Christ 97 (VIES); 21.VIII.2015, fl., J.A. Christ 98 (VIES).

Piper aduncum resembles $P$. macedoi by the elliptical leaf blade with a similar type of venation and dimensions and secondary veins anastomosed in the leaf margin, but differs by the curved spikes. The species occurs in all states of Brazil, except in the states of Rio Grande do Norte and Sergipe (BFG 2015). In the state of Espírito Santo, there are collections for the municipalities of Alfredo Chaves, Domingos Martins, Ibitirama, Itarana, Iúna, Linhares, Marechal Floriano, Nova Venécia, Santa Teresa, São Roque do Canaã, Serra, Venda Nova do Imigrante and Vitória (Species Link 2015). Few and isolated individuals of $P$. aduncum were observed always near from roadsides in the PEMF. Flower in May to November.

\section{Piper amalago $\mathrm{L}$.}

Fig. 2d-f

Shrub $2 \mathrm{~m}$ tall, branches pilose, branches without protrusions, internodes ranging 2.3-10 $\mathrm{cm}$. Petiole striate, sheath invaginating, $0.5-1.3$ $\mathrm{cm}$ long, pilose, not overlapping the base of the leaf blade. Leaf blade symmetric, chartaceous,
6.6-15.1 × 3.9-10 cm, deltoid, pilose on abaxial veins, base symmetric, round, apex attenuated, acrodomous venation, 4-7 pairs of secondary veins arcuate, arranged up to the middle of the main vein, not prominent on the face abaxial, anastomosed on the margin, margin entire. Spike solitary, erect, $2.4-8 \mathrm{~cm}$ long, peduncle pilose. Flower not pedicellate, floral bract round, pubescent fimbriate, 5-6-stamens without glands, ovary glabrous, inconspicuous stylus, 3-stigma, thick. Fruits not pedicellate, globose, glabrous.

Selected specimens examined: 6.IV.2013, fr., T.T. Carrijo et al. 1722 (VIES); 2.II.2012, fl. e fr., T.T. Carrijo et al. 1628 (VIES); 16.V.2013, fl., J.A. Christ 02 (VIES); 17.XI.2014, fl., J.A. Christ 42 (VIES); 17.XI.2014, fl., J.A. Christ 43 (VIES).

Piper amalago differs from other Piper species occurring in the MFSP by deltoids leaves with acrodomous venation. The species occurs in Alagoas, Bahia, Ceará, Distrito Federal, Espírito Santo, Goiás, Mato Grosso, Mato Grosso do Sul, Minas Gerais, Pará, Paraíba, Paraná, Pernambuco, Rio de Janeiro, Rio Grande do Sul, Rondônia, Santa Catarina, São Paulo and Sergipe (BFG 2015). In the state of Espírito Santo, the species were collected in the municipalities of Anchieta, Cachoeiro de Itapemirim, Castelo, Conceição da Barra, Guarapari, Iconha, Itapemirim, Linhares, Marataízes, Mimoso do Sul, Nova Venécia, Santa Teresa, Serra, Sooretama, Vila Velha and Vitória (Species Link 2015). Piper amalago is a frequent species in MFSP, showing an aggregated spatial distribution, and always near roadsides. Flower on October to February, and fruits on February to April.

3. Piper anisum (Spreng.) Angely Fig. 2g-h

Shrub $2 \mathrm{~m}$ tall, branches pubescent, without protrusions, internodes ranging $2.8-6 \mathrm{~cm}$. Petiole striate, sheath short, $0.2-0.5 \mathrm{~cm}$ long, glabrous, not overlapping the base of the leaf blade. Leaf blade symmetric, chartaceous, $5.9-18.6 \times 2.5-7.6 \mathrm{~cm}$, asymmetric-elliptical, puberulous on abaxial veins, more densely pilose on midrib, base asymmetric, subcordate, one size ca. $2 \mathrm{~mm}$ shorter at the petiole, apex acute to acuminate, brochidrodomous venation, $7-10$ pairs of secondary veins arcuate up 

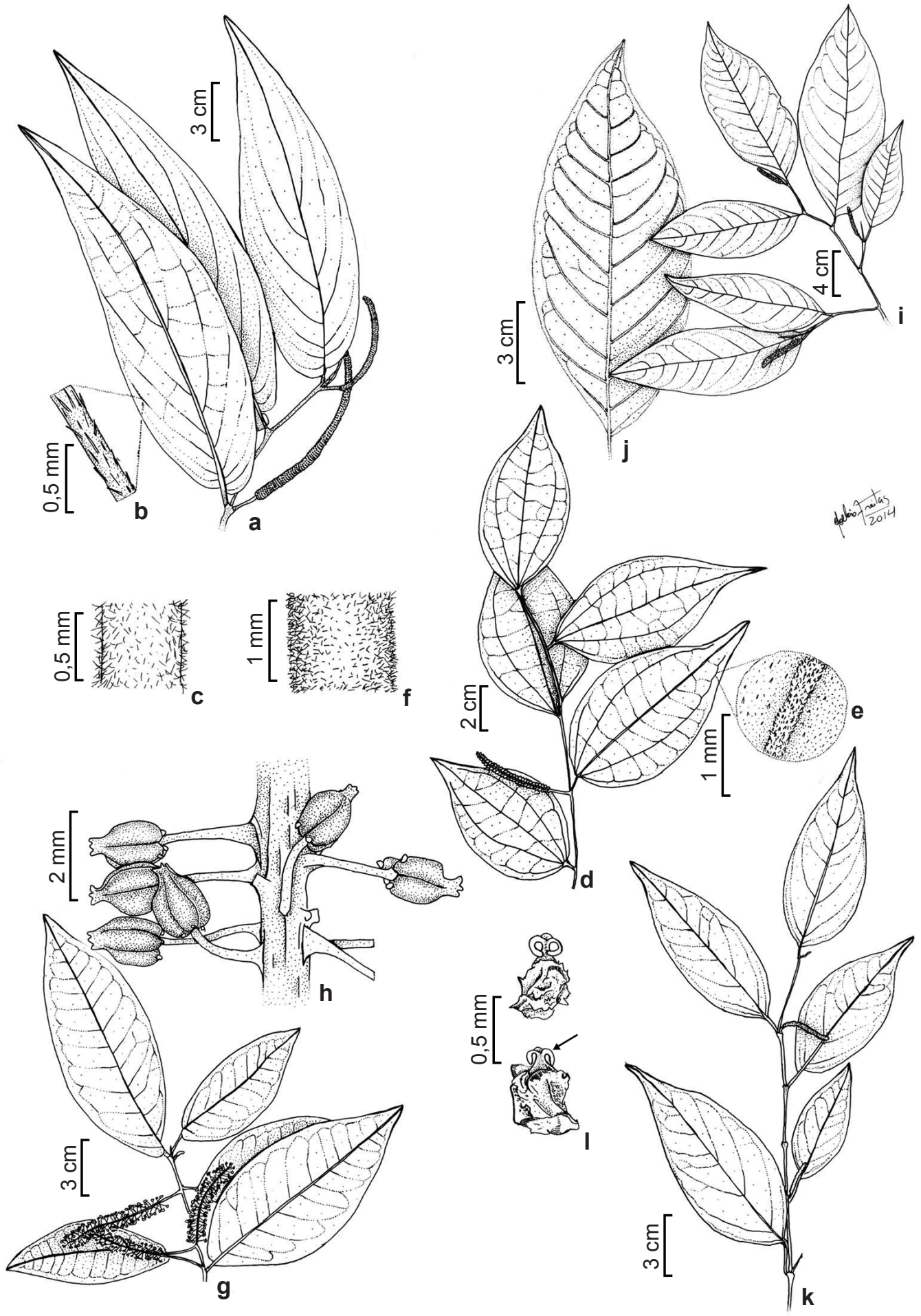

Figure 2 - a-c. Piper aduncum L. (J.A.Christ et al. 03) - a. branches with spike; b. detail of trichomes in secondary veins; c. detail of trichomes in branches. d-f. Piper amalago L. (T.T. Carrijo et al. 1722) - d. branches with spike; e. detail of trichomes in secondary veins; f. detail of trichomes in branches. g-h. Piper anisum (Spreng.) Angely. (T.T. Carrijo et al. 1693) - g. branch with spike; h. detail of the infructescence with pedicellate fruits. i-j. Piper bicorne M. Carvalho-Silva, E.F. Guim. \& L.A. Pereira (T.T. Carrijo et al. 1632) - i. branch with spike; j. detail form leaf and veins form. k-1. Piper bowiei Yunck. (J.A.Christ et al. 12) - k. branch with spike; 1. detail of stigma ligulate (at arrow). 
to the apex, arranged up to apex of the main vein, not prominent on the face abaxial, anastomosed on the margin, margin entire. Spike solitary, erect, 4.5-6.6 cm long, 0.52-1 cm diam., peduncle pilose. Flower no seen. Fruit pedicellate, globosetetragonal, glabrous.

Selected specimens examined: 4.II.2013, fr., T.T. Carrijo et al. 1654 (VIES); 19.I.2013, fr., T.T. Carrijo et al. 1614 (VIES); 4.III.2013, fr., T.T. Carrijo et al. 1690 (VIES); 4.III.2013, fr., T.T. Carrijo et al. 1693 (VIES); 17.III.2014, fr., T.T. Carrijo et al. 2030 (VIES); 16.V.2013, fr., J.A. Christ et al. 04 (VIES); 16.V.2013, fr., J.A. Christ 5 (VIES); 16.V.2013, fr., J.A. Christ 6 (VIES); 4.XII.2014, fr., J.A. Christ 59 (VIES).

Piper anisum resembles $P$. miquelianum by the internodes evident, brochidrodomous venation and pedicellate fruits, but differs puberulous on abaxial veins, and spike larger than $3.4 \mathrm{~cm}$. The species occurs Bahia, Espírito Santo, Minas Gerais, Pernambuco, Rio de Janeiro and São Paulo (BFG 2015). In the State of Espírito Santo, the species were collected in the municipalities of Alegre, Cariacica, Castelo, Conceição do Castelo, Itarana, Santa Leopoldina, Santa Maria de Jetibá, Santa Teresa and Vargem Alta (Species Link 2015). Piper anisum is an understory species that shows aggregated spatial distribution, occurring preferentially in hillsides. Fruits on December to March.

\section{Piper arboreum Aubl.}

Shrub $3 \mathrm{~m}$ tall, branches glabrous, without protrusions, internodes ranging 4.9-7 cm. Petiole canaliculate, sheath invaginating, $1-2.5 \mathrm{~cm}$, glabrous, not overlapping the base of the leaf blade. Leaf blade symmetric, chartaceous, 13-18 $\times 5.4-6.63 \mathrm{~cm}$, elliptical to slightly lanceolate, glabrous, base asymmetric, round, one size 13-26 $\mathrm{mm}$ shorter at the petiole, apex acute to acuminate, eucamptodromous venation, 8 pairs of secondary veins arcuate, arranged up to apex of the main vein, not prominent on the face adaxial, venation not anastomosed at the margin, margin entire. Spike solitary, erect, $3.2-5.5 \mathrm{~cm}$ long, $0.15-0.25 \mathrm{~cm}$ diam., peduncle glabrous. Flower not pedicellate, floral bract triangular, glabrous, 4 stamens without glands, ovary glabrous, inconspicuous stylus, 3-stigma, filiform. Fruit not seen.

Selected specimens examined: 17.XII.2014, f1., J.A. Christ et al. 89; 17.XI.2014, fl., J.A. Christ 26 (VIES).

Piper arboreum resembles Piper pubisubmarginalum by the leaf blade symmetric elliptic and spike erect, but differs by the base of the leaf blade asymmetric. The species occurs in all states of Brazil, except in the state of Maranhão and Rio Grande do Norte (BFG 2015). In the state of Espírito Santo, the species was collected in the municipalities of Águia Branca, Alegre, Anchieta, Cariacica, Colatina, Conceição do Castelo, Domingos Martins, Ibiraçu, Iconha, Itaúnas, Itapemirim, Linhares, Marechal Floriano, Marilândia, Mimoso do Sul, Nova Venécia, Rio Bananal, Santa Leopoldina, Santa Maria de Jetibá, Santa Teresa, São Lourenço, São Mateus, Serra, Sooretama, Vargem Alta, Viana, Vila Pavão and Vitória (Species Link 2015). Just two individuals of this species were observed in MFSP, occurring in the understory near from a narrow trail within the forest. Flower on November and December.

5. Piper bicorne Carv.-Silva, E.F.Guim. \& L.A.Pereira

Fig. $2 \mathrm{i}-\mathrm{j}$

Shrub 1.5-2 m tall, branches glabrous, without protrusions, internodes ranging $3.6-4.4 \mathrm{~cm}$. Petiole canaliculate, sheath short, $0.28-0,61 \mathrm{~cm}$, glabrous, not overlapping the base of the leaf blade. Leaf blade symmetric, chartaceous, 11.3-16.6 $\times \quad 3.5-6 \mathrm{~cm}$, elliptic, glabrous, base symmetric, obtuse, apex acuminate, eucamptodromous venation, 7-10 pairs of secondary veins arcuate, arranged up to apex of the main vein, not prominent on the face adaxial, venation not anastomosed at the margin, margin entire. Spike solitary, erect, 2.5-4.1 cm long, 0.27-0.49 diam., peduncle glabrous. Flower not seen. Fruit not pedicellate, angulate, glabrous.

Selected specimens examined: 2.II.2013, fr., T.T. Carrijo et al. 1632 (VIES).

Piper bicorne resembles $P$. piliovarium by the leaf blade symmetric and venation shape, but differs by the base of the leaf blade obtuse. This species is endemic to Espírito Santo state, and was recently published based on a collection from the municipality of Santa Leopoldina (Carvalho-Silva et al. 2015). The collection T.T. Carrijo et al. 1632 (VIES) expands the geographic distribution of the species in Espírito Santo, from the municipality of Castelo. Just one individual of Piper bicorne was found in MFSP, occurring in the forest understory of valley areas. Fruits in February.

6. Piper bowiei Yunck.

Fig. 2k-1

Shrub $1.5 \mathrm{~m}$ tall, branches glabrous, without protrusions, internodes ranging $4.9-7 \mathrm{~cm}$. Petiole canaliculate, sheath short, 0.9-1.9 cm long, glabrous, not overlapping the base of the leaf blade. Leaf blade symmetric, chartaceous, 6.3-11.8 
$\times 2.7-4.8 \mathrm{~cm}$, elliptical to slightly lanceolate, glabrous, base symmetric, acute, apex acute to acuminate, eucamptodromous venation, 4 pairs of secondary veins arcuate, arranged up to the middle of the main vein, not prominent on the face abaxial, venation not anastomosed at the margin, margin entire. Spike solitary, erect, 3.2-5.2 $\mathrm{cm}$ long, $0.15-0.19 \mathrm{~cm}$ diam., peduncle pilose. Flower not pedicellate, floral bract cuculate, pubescent fimbriate, 4-stamens without glands, ovary glabrous, stylus long, 3-stigma, ligulate. Fruit not seen.

Selected specimens examined: 21.XIII.2015, fl., J.A. Christ 93 (VIES); 21.XIII.2015, fl., J.A. Christ 94 (VIES).

Piper bowiei resembles $P$. caldense by the leaf blade symmetric and venation shape and leaf base acute, but differs by the glabrous branches, but differs from this species (and also for the others species) by the leaf blade with four pairs of secondary veins and ligulate stigma. The species occurs at Amazonas, Bahia, Espírito Santo, Rio de Janeiro and São Paulo (BFG 2015). In the state of Espírito Santo, P. bowiei was previously collected just on the municipality of Iúna by G.G. Hatschbach n. 3135 (NY, MO, MBM) (Species Link 2015). The collection Christ et al. 12 recorded the species in ES for the second time. Piper bowiei is an understory species in MFSP, occurring at hill slopes near watercourses. Just two individuals, close to each other, were observed. Flowers in August.

\section{Piper caldense C.DC.}

Fig. 3a-b

Shrub $1.5 \mathrm{~m}$ tall, branches glabrous, without protrusions, internodes ranging $2-6 \mathrm{~cm}$. Petiole canaliculate, sheath short, $0.4-0.85 \mathrm{~cm}$ long, glabrous, not overlapping the base of the leaf blade. Leaf blade symmetrical, chartaceous, 8.5-20.6 $\times$ cm 2.7-8.1, elliptical, glabrous, base asymmetric, acute, one size 6-9 $\mathrm{mm}$ shorter at the petiole, apex acute, eucamptodromous venation, 5-7 pairs of secondary veins arcuate, arranged up to apex of the main vein, not prominent on the face adaxial, venation anastomosed at the margin, margin entire. Spike solitary, pendulum, $2.1-4.4 \mathrm{~cm}$ long, $0.45-0.75 \mathrm{~cm}$ diam., peduncle glabrous. Flower not pedicellate, floral bract triangular, pubescent fimbriate, 4-stamens with glands, ovary glabrous, stylus inconspicuous, 3-stigma, filiform. Fruit not pedicellate, globose, glabrous.

Selected specimens examined: 13.II.2014, fr., J.A. Christ et al. 21 (VIES); 17.V.2013, fl., T.T. Carrijo et al. 1645 (VIES); 17.III.2014, fr., T.T. Carrijo et al. 2043 (VIES); 15.I.2014, fl., T.T. Carrijo et al. 1975 (VIES).
Piper caldense resembles $P$. permucronatum by the petiole canaliculate and by the leaves with similar foliar dimensions, number and position of the secondary veins. However, $P$. caldense differs from $P$. permucronatum, as well as from the others species occurring at the MFSP, by the secondary venation glabrous on the abaxial side of the leaves and by the spikes pendulum. The species occurs in Alagoas, Bahia, Ceará, Distrito Federal, Espírito Santo, Goiás, Minas Gerais, Paraíba, Paraná, Pernambuco, Rio de Janeiro, Santa Catarina and São Paulo (BFG 2015). In ES, P. caldense was collected on the municipalities of Afonso Cláudio, Águia Branca, Atílio Vivácqua, Castelo, Guarapari, Iúna, João Neiva, Linhares, Santa Teresa and Sooretama (Species Link 2015). Piper caldense is a relative common understory species, observed in spatially aggregated populations. Flower in January to May and fruits in February to March.

\section{Piper cernuum Vell.}

Shrub $5 \mathrm{~m}$ tall, branches glabrous, without protrusions, internodes ranging $6.5-10 \mathrm{~cm}$. Petiole canaliculate, sheath invaginating, 3-6.3 cm, glabrous, not overlapping the base of the leaf blade. Leaf blade asymmetric, chartaceous, 20.4-43.6 $\times$ $8.7-15.1 \mathrm{~cm}$, elliptical, glabrous, base asymmetric, cordate, one size $23-58 \mathrm{~mm}$ shorter at the petiole, apex acute, eucamptodromous venation, 8 pairs of secondary veins arcuate, arranged up to apex of the main vein, not prominent on the face adaxial, venation not anastomosed at the margin, margin entire. Spike solitary, pendulum, $15.4-35.7 \mathrm{~cm}$ long, $0.45-0.78 \mathrm{~cm}$ diam., peduncle glabrous. Flower not pedicellate, floral bract triangular, glabrous, 4 stamens without glands, ovary glabrous, inconspicuous stylus, 3 -stigma, ligulate. Fruit not seen.

Selected specimens examined: 16.IV.2015, fl., J.A. Christ et al. 92 (VIES).

Piper cernuum resembles $P$. caldense by the spike pendulum, but differs by the large spike. The species occurs in Acre, Alagoas, Amapá, Amazonas, Bahia, Ceará, Distrito Federal, Espírito Santo, Goiás, Mato Grosso, Mato Grosso do Sul, Minas Gerais, Pará, Paraná, Pernambuco, Rio de Janeiro, Rio Grande do Sul, Rondônia, Santa Catarina, São Paulo and Tocantins (BFG 2015). In $\mathrm{ES}$, the species were collected in the municipalities of Águia Branca, Alegre, Alfredo Chaves, Baixo Guandu, Cariacica, Castelo, Domingos Martins, Itaguaçu, Marechal Floriano, Rio Novo, Santa Teresa, São Lourenço, Vargem Alta and Venda 

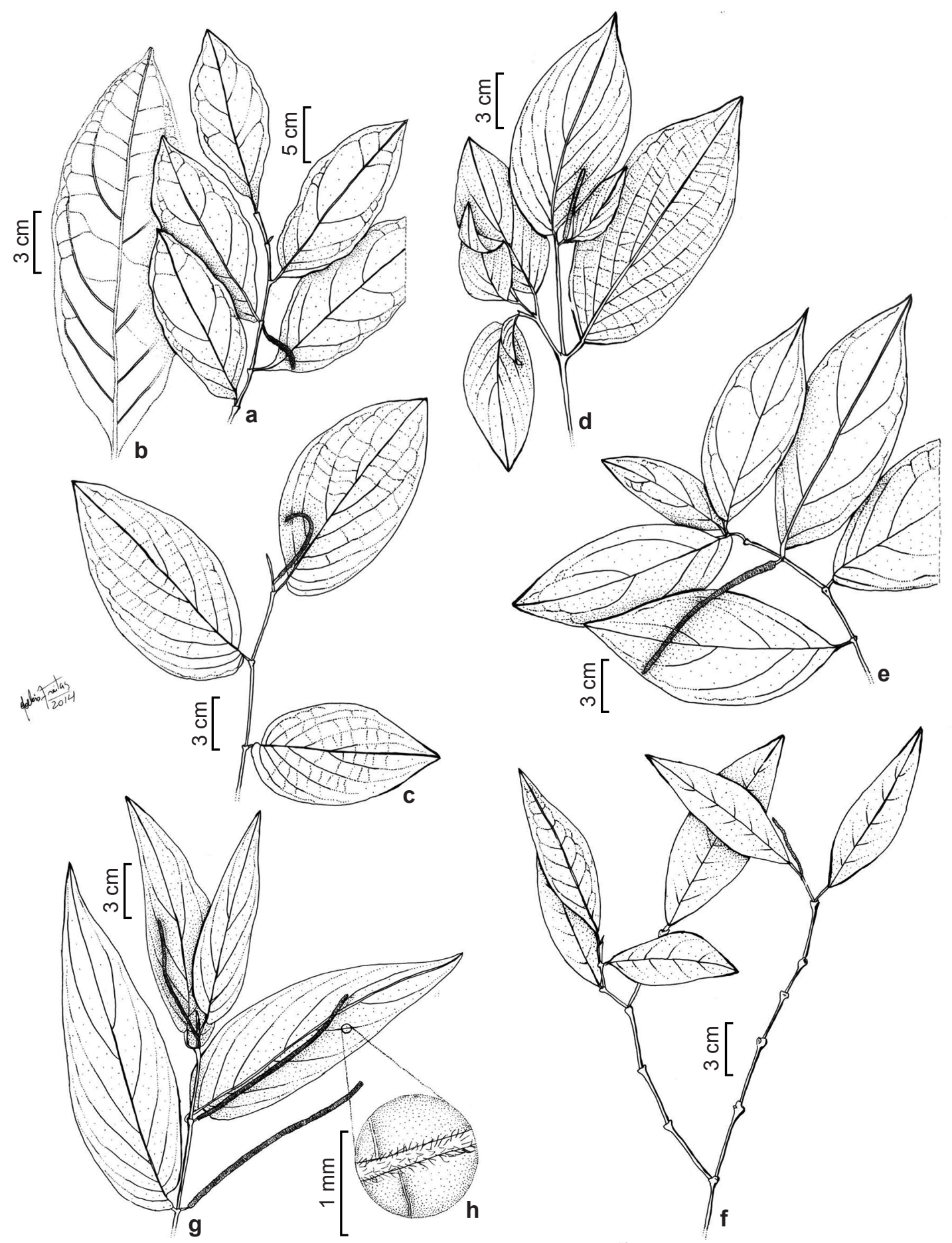

Figure 3 - a-b. Piper caldense C.DC. (T.T.Carrijo et al. 1645) - a. branch with spike; b. detail of veins abaxial face. c. Piper dilatatum Rich. (J.A. et al. Christ 01) - branch with spike. d. Piper gaudichaudianum Kunth. (T.T. Carrijo et al. 1612) - branch with spike. e. Piper glabratum Kunth (T.T. Carrijo et al. 1585) - branch with spike. f. Piper hoffmannseggianum Roem. \& Schult. (T.T.Carrijo et al. 1543) - branch with spike. g-h. Piper macedoi Yunck. (T.T.Carrijo et al. 1586) - g. branch with spikes; h. detail of trichomes in secondary veins. 
Nova (Species Link 2015). Just one individual of P. cernuum was observed in the MFSP, occurring near watercourses. This is an understory species, and the individual was observed near a narrow trail within the forest. Flowers in April.

\section{Piper dilatatum Rich.}

Fig. 3c

Shrub $2 \mathrm{~m}$ tall, branches puberulous, without protrusions, internodes ranging $4.7-6.5 \mathrm{~cm}$. Petiole striate, sheath short, $0.28-0.49 \mathrm{~cm}$ long, pilose, not overlapping the base of the leaf blade. Leaf blade asymmetric, chartaceous, 8.7-15.1 ×6.9-4.5 $\mathrm{cm}$, elliptical to ovate, puberulous mainly on the abaxial venation, base asymmetric, acute, one size 4-8 $\mathrm{mm}$ shorter at the petiole, apex attenuate, eucamptodromous venation, 5 pairs of secondary veins straight, arranged up to the middle of the main vein, venation, not prominent on the face adaxial, not anastomosed at the margin, margin entire. Spike solitary, curved, 4.2-5.2 cm long, $0.17-0.21 \mathrm{~cm}$ diam., peduncle puberulous. Flower not pedicellate, floral bract round, pubescent fimbriate, 4-stamens without glands, ovary glabrous, stylus inconspicuous, 3-stigma, filiform. Fruits not seen.

Selected specimens examined: 16.V.2013, fl., J.A. Christ et al. 01 (VIES, RB); 19.X.2013, fl., J.A. Christ et al. 08 (VIES); 11.XII.2014, f1., J.A. Christ 73 (VIES); 11.XII.2014, fl., J.A. Christ 74 (VIES).

Piper dilatatum resembles P. gaudichaudianum by the leaf base acute, asymmetric, secondary veins straight and curved spike, but differs by the leaf blade with apex attenuate and floral bracts round. The species occurs in Acre, Alagoas, Amapá, Amazonas, Bahia, Ceará, Distrito Federal, Espírito Santo, Goiás, Maranhão, Mato Grosso, Mato Grosso do Sul, Minas Gerais, Pará, Paraíba, Paraná, Pernambuco, Rio de Janeiro, Rio Grande do Sul, Rondônia, Roraima, Santa Catarina, São Paulo and Tocantins (BFG 2015). The first record of $P$. dilatatum in ES resulted from a collection made at MFSP, and was updated at BFG (2015). Individuals of this species were observed just near roadsides and were grouped in space, always near $P$. gaudichaudianum individuals. Flowers in October to May.

\section{Piper gaudichaudianum Kunth}

Fig. 3d

Shrub $2 \mathrm{~m}$ tall, branches pilose, without protrusions, internodes ranging $3-7.2 \mathrm{~cm}$. Petiole striate, sheath short, $0.32-0.76 \mathrm{~cm}$ long, pilose, not overlapping the base of the leaf blade. Leaf blade asymmetric, chartaceous, 6.7-15 × 2.9-6.7 $\mathrm{cm}$, elliptical, sometimes asymmetric, scabrous mainly at the abaxial venation, base asymmetric, acute, one size $2-4 \mathrm{~mm}$ shorter at the petiole, apex acute to acuminate, eucamptodromous venation, 5 pairs of secondary veins straight arranged up to or little above the middle of the main vein, not prominent on the face adaxial, venation not anastomosed at the margin, margin entire. Spike solitary, curved, 3-6.7 cm long, peduncle pilose. Flower not pedicellate, floral bract triangular, pubescent fimbriate, 4-stamens without glands, ovary glabrous, stylus inconspicuous, 3-stigma, filiform. Fruits not pedicellate, oblong, laterally flattened, glabrous.

Selected specimens examined: 19.I.2013, fl. e fr., T.T. Carrijo et al. 1612 (VIES); 17.XI.2014, fl., J.A. Christ 44 (VIES); 17.XI.2014, fl., J.A. Christ 45 (VIES); 17.XI.2014, fl., J.A. Christ 46 (VIES).

Piper gaudichaudianum resembles $P$. dilatatum by the leaf base acute, asymmetric, secondary veins straight and curved spike, but differs by the apex of the leaf blade acute to acuminate and floral bracts triangular. This species occurs in Alagoas, Bahia, Ceará, Distrito Federal, Espírito Santo, Maranhão, Mato Grosso, Mato Grosso do Sul, Minas Gerais, Pará, Paraná, Pernambuco, Rio de Janeiro, Rio Grande do Sul, Santa Catarina and São Paulo (BFG 2015). In ES, P. gaudichaudianum was collected on the municipalities of Águia Branca, Castelo, Cachoeiro de Itapemirim, Linhares, Santa Leopoldina, Santa Teresa, Sooretama and Venda Nova do Imigrante (Species Link 2015). Individuals of Piper gaudichaudianum, as well as of $P$. dilatatum, were observed just near roadsides and were grouped in space. Flowers in November to January and fruits in January.

\section{Piper glabratum Kunth}

Fig. 3e

Shrub $1.5 \mathrm{~m}$ tall, branches glabrous, without protrusions, internodes ranging $2-4.4 \mathrm{~cm}$. Petiole striate, sheath short, $0.22-0.67 \mathrm{~cm}$ long, glabrous, not overlapping the base of the leaf blade. Leaf blade symmetric, chartaceous, 10-17.2 × 3.9-7.5 $\mathrm{cm}$, elliptical, puberulous at the abaxial venation, base asymmetric, acute, one size 3-6 mm shorter at the petiole, apex acute to acuminate, eucamptodromous venation, 4 pairs of secondary arcuate, veins arranged up to or little above the middle of the main vein, not prominent on the face adaxial, not prominent on the ace adaxial, venation not anastomosed at the margin, margin entire. Spike solitary, curve or slightly curved, 
$3.3-11 \mathrm{~cm}$ long, peduncle glabrous. Flower not pedicellate, floral bract round, pubescent, 4-stamens without glands, ovary glabrous, stylus inconspicuous, 3-stigma, filiform. Fruits not pedicellate, obpyramidal, angular, glabrous.

Selected specimens examined: 15.I.2013, fl. e fr., T.T. Carrijo et al. 1585 (VIES); 11.XII.2014, fl., J.A. Christ 77 (VIES); 11.XII.2014, fl., J.A. Christ 78 (VIES).

Piper glabratum resembles $P$. macedoi by leaves with asymmetric base and apex acute, but differs branches glabrous, leaves with pilosity puberulous at the abaxial side, 4-pairs of secondary veins, and fruits with an angular shape. This species occurs in Acre, Alagoas, Bahia, Distrito Federal, Espírito Santo, Goiás, Mato Grosso, Mato Grosso do Sul, Minas Gerais, Pará, Paraíba, Paraná, Pernambuco, Rio de Janeiro, Rondônia, and São Paulo (BFG 2015). In ES, the species was collected on the municipalities of Vila Velha, Vitória, and Serra (Species Link 2015). Four individuals of $P$. glabratum were observed occurring near roadsides. Flowers on December to January and fruits in January.

\section{Piper hoffmannseggianum Roem. \& Schult.}

Fig. $3 \mathrm{f}$

Shrub $1 \mathrm{~m}$ tall, branches glabrous, without protrusions, internodes ranging $3.2-4.2 \mathrm{~cm}$. Petiole canaliculate, sheath short, $0.52-0.85 \mathrm{~cm}$ long, glabrous, not overlapping the base of the leaf blade. Leaf blade symmetric, chartaceous, 2.2-3.2 $\times$ $9.2-10.5 \mathrm{~cm}$, elliptical, glabrous, base symmetric, acute, apex acute to acuminate, camptodromous venation, 7-8 pairs of secondary arcuate, arranged up to apex of the main vein, not prominent on the face adaxial, venation not anastomosed at the margin, margin entire. Spike solitary, erect, 2.8-3.3 $\mathrm{cm}$ long, peduncle glabrous. Flower not pedicellate, floral bract triangular, glabrous, 4-stamens without glands, ovary glabrous, stylus inconspicuous, 4-stigma, filiform. Fruit not seen.

Selected specimens examined: 17.XII.2012, fl., T.T. Carrijo et al. 1543 (VIES).

Piper hoffmannseggianum resembles $P$. piliovarium by the short internodes and leaf blade shape, but differs by the base of the leaf blade acute. This species occurs in Distrito Federal, Espírito Santo, Minas Gerais, Pará, Paraná, Rio de Janeiro, and São Paulo (BFG 2015). In ES, the species was collected in the municipalities of Santa Leopoldina and Santa Teresa (Species Link 2015). Just one individual of this species was observed in MFSP, occurring in the forest understory. Flowers in December.
13. Piper macedoi Yunck.

Fig. 3g-h

Shrub $1.5 \mathrm{~m}$ tall, branches pilose, without protrusions, internodes ranging $5-5.7 \mathrm{~cm}$. Petiole canaliculate, sheath short, $0.38-0.52 \mathrm{~cm}$ long, pilose, not overlapping the base of the leaf blade. Leaf blade asymmetric, chartaceous, 11-20 $\times$ $2.9-6 \mathrm{~cm}$, elliptical, pilose on the abaxial venation, base asymmetric, acute, one size $2-4 \mathrm{~mm}$ shorter at the petiole, apex acute to acuminate, eucamptodromous venation, 5-6 pairs of secondary veins arcuate, arranged up to apex of the main vein, not prominent on the face adaxial, venation anastomosed at the margin, margin entire. Spike solitary, erect, $9.3-11.3 \mathrm{~cm}$ long, peduncle pilose. Flower not seen. Fruit not pedicellate, angle, oblong, glabrous.

Selected specimens examined: 15.I.2013, fr., T. $T$. Carrijo et al. 1586 (VIES).

Piper macedoi resembles $P$. glabratum by leaves with asymmetric base and apex acute, but differs branches pilose, leaves with pilosity at the abaxial side, 5-6 pairs of secondary veins and fruits with angular shape. This species occurs in the states of Bahia, Ceará, Distrito Federal, Espírito Santo, Goiás, Maranhão, Mato Grosso, Mato Grosso do Sul, Minas Gerais, Paraná, Rio de Janeiro, Santa Catarina, and São Paulo (BFG 2015). The first record of $P$. macedoi in ES resulted from a collection made at MFSP, and was updated in the BFG (2015). In MFSP, this species occurs near from the roadside. Fruits in January.

14. Piper miquelianum C. DC.

Fig. 4a-b

Shrub $0.5 \mathrm{~m}$ tall, branches pilose, without protrusions, internodes ranging $2.2-6.3 \mathrm{~cm}$. Petiole striate, sheath short, $0.22-0.41 \mathrm{~cm}$ long, puberulous, overlapping the base of the leaf blade. Leaf blade symmetric, chartaceous, 4.6-13.7 × 3.2$8.6 \mathrm{~cm}$, elliptical or ovate, pilose, base asymmetric, subcordate, one size ca. $2 \mathrm{~mm}$ shorter at the petiole, apex attenuate, brochidrodomous venation, 8-10 pairs of secondary veins arcuate, arranged up to apex of the main vein, not prominent on the face adaxial, venation not anastomosed at the margin, margin entire. Spike solitary, erect, $2.8-3.4 \mathrm{~cm}$ long, peduncle pilose. Flower pedicellate, floral bract round, glabrous, 4-stamens without glands, ovary glabrous, stylus inconspicuous, 4-stigma, acute. Fruit not seen.

Selected specimens examined: 10.XII.2013, fl., J.A. Christ et al. 16 (VIES); 17.XI.2014, f1., J.A. Christ 25 (VIES); 17.XI.2014, fl., J.A. Christ 28 (VIES); 4.XII.2014, fl., J.A. Christ 48 (VIES); 5.XII.2014, fr., J.A. Christ 65 (VIES). 
Piper miquelianum resembles $P$. anisum by the brochidrodomous venation and pedicellate flowers, but differs from this species by the leaf blade pilose and spike up to $3.4 \mathrm{~cm}$ long. This species occurs in Bahia, Minas Gerais, Paraná,
Rio Grande do Sul, Santa Catarina, São Paulo (BFG 2015) and Espírito Santo (Species Link 2015). This species was not listed from ES by BFG (2015). However, besides the collection made at MFSP reported here, P. miquelianum

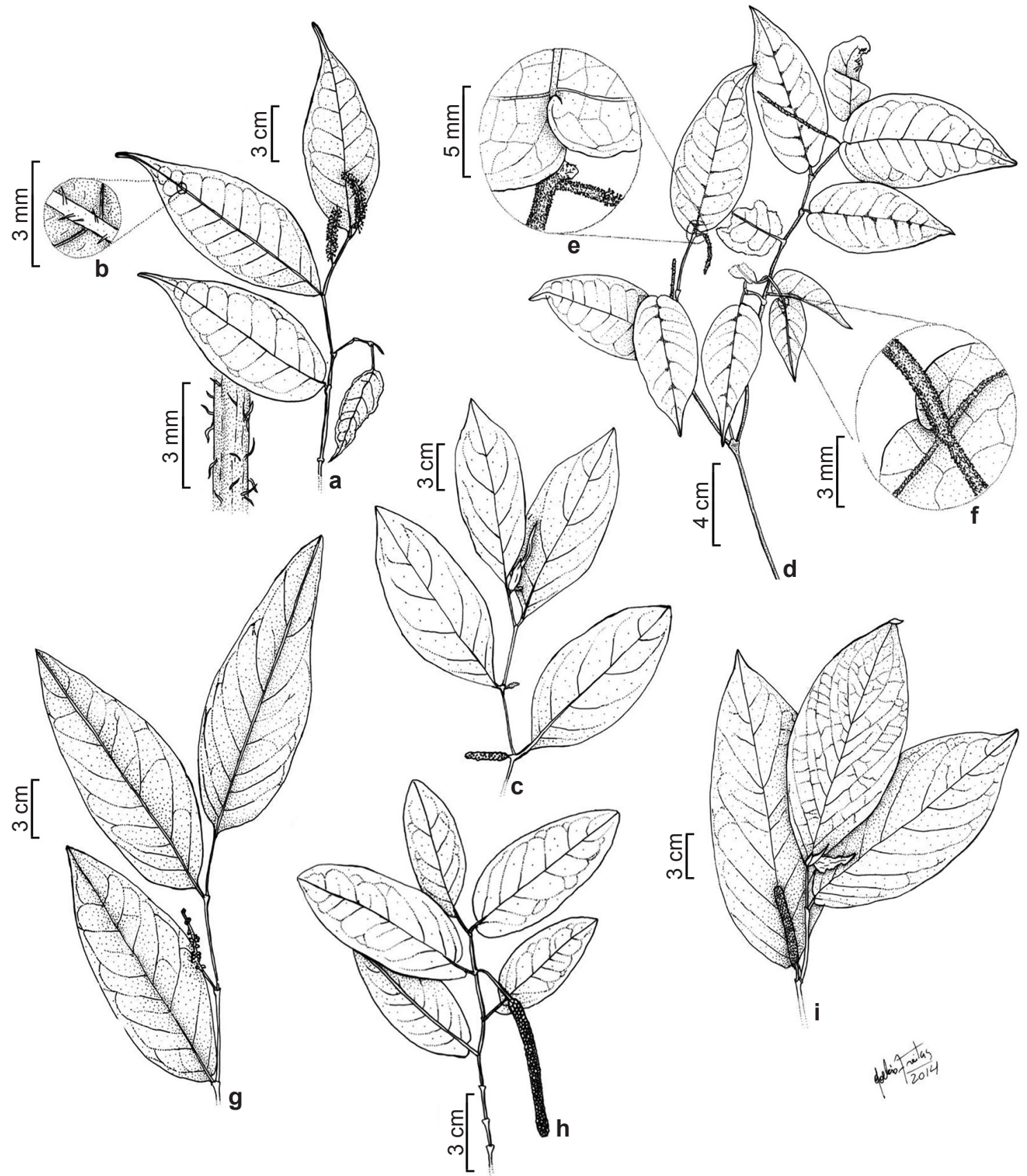

Figure 4 - a-b. Piper miquelianum C.DC. (J.A.Christ et al. 16) - a. branch with spikes; b. detail of trichomes in branch. c. Piper permucronatum C.DC. (J.A.Christ et al. 7) - branch with spikes. d-f. Piper piliovarium Yunck. (T.T.Carrijo et al. s.n.) - d. branch with spikes; e. detail leaf whit base asymmetric; f. detail of trichomes petiole. g. Piper pubisubmarginalum Yunck. (T.T. et al. Carrijo 1688) - branch with spike. h. Piper tuberculatum Jacq. (T.T.Carrijo et al. 1666) - branch with spike; i. Piper vicosanum Yunck. (J.A.Christ et al. 17) - branch with spike. 
was previously collected on the municipalities of Castelo, Domingos Martins and Linhares (Species Link 2015). In MFSP, groups with 3-6 individuals were observed exclusively near watercourses in the forest understory. Flowers in November and December.

\section{Piper permucronatum Yunck.}

Fig. 4c

Shrub 2 m tall, branches glabrous, without protrusions, internodes ranging $2.1-6.3 \mathrm{~cm}$. Petiole canaliculate, sheath short, $0.37-0.81 \mathrm{~cm}$ long, glabrous, not overlapping the base of the leaf blade. Leaf blade symmetric, chartaceous, 10.9-15.8 × 3.8-6.6 cm, elliptical, puberulous on the abaxial venation, base asymmetric, acute, one size 2-6 mm shorter at the petiole, apex acute, eucamptodromous venation, 5-7 pairs of secondary veins arcuate, arranged up to apex of the main vein, not prominent on the face adaxial, venation anastomosed at the margin, margin repand. Spike erect, 2.4-3.3 cm long, peduncle glabrous. Flower not pedicellate, floral bract triangular, pubescent fimbriate, 4-stamens without glands, ovary glabrous, stylus inconspicuous, 3-stigma, filiform. Fruit not pedicellate, globose, glabrous.

Selected specimens examined: 25.II.2013, fl., T.T. Carrijo et al. 1668 (VIES); 17.V.2014, fr., J.A. Christ et al. 7 (VIES).

Piper permucronatum resembles $P$. caldense by the petiole canaliculate, by the size of the foliar blade and by the similar number of secondary veins, but differs in the secondary venation puberulous on the abaxial side of the leaves and by the spikes erect. This species occurs in the states of Bahia, Espírito Santo, Minas Gerais, Paraná, Rio de Janeiro, and São Paulo (BFG 2015). In ES, the species was previously collected by the municipality of Castelo (Goldenberg, $R$. UPCB 76345) (Species Link 2015). In MFSP, $P$. permucronatum is an understory species. Flowers in February and fruits in May.

\section{Piper piliovarium Yunck.}

Fig. 4d-f

Shrub 1-1.5 m tall, branches glabrous, without protrusions, internodes ranging 1.1-5.1 $\mathrm{cm}$. Petiole striate, sheath short, $0.16-0.47 \mathrm{~cm}$ long, pilose, not overlapping the base of the leaf blade. Leaf blade symmetric, chartaceous, 5.4-11.3 $\times 2.2-3.8 \mathrm{~cm}$, elliptical, glabrous, asymmetric, base cordate, one size $2-4 \mathrm{~mm}$ shorter at the petiole, apex acute, eucamptodromous venation, 7-9 pairs of secondary veins curved, arranged up near to apex of the main vein, not prominent on the face adaxial, venation not anastomosed at the margin, margin entire. Spike solitary, erect, 3.4-4.9 cm long, peduncle glabrous. Flower not pedicellate, floral bract triangular, pubescent fimbriate, 4-stamens without glands, ovary pilose, stylus inconspicuous, 4-stigma, filiform. Fruits not pedicellate, globose, glabrous.

Selected specimens examined: 17.II.2013, fl. E fr., T.T. Carrijo et al. (VIES 35622); 2.II.2013, fr., T.T. Carrijo et al. 1632 (VIES); 17.XI.2014, fl., J.A. Christ 33 (VIES); 17.XI.2014, fl., J.A. Christ 34 (VIES); 17.XI.2014, fl., J.A. Christ 35 (VIES); 17.XI.2014, fl., J.A. Christ 27 (VIES); 4.XII.2014, fl., J.A. Christ 52 (VIES).

Piper piliovarium resembles $P$. hoffmannseggianum by the short internodes, but differs by the leaves with camptodromous venation and apex acute. This species occurs in the Sates of Minas Gerais and Rio de Janeiro (BFG 2015). The collection T.T. Carrijo et al. (VIES 35622) is the first record of $P$. piliovarium in ES, and was not updated in the BFG (2015). In MFSP, this is an understory species. The individuals show an aggregated distribution in space, occurring in areas of valleys. Flower on November to February and fruits on February.

\section{Piper pubisubmarginalum Yunck.}

Fig. $4 \mathrm{~g}$

Shrub 1.5-2 m tall, branches glabrous, without protrusions, internodes ranging 3.8-4.3 $\mathrm{cm}$. Petiole striate, sheath short, $0.32-0.88 \mathrm{~cm}$ long, glabrous, not overlapping the base of the leaf blade. Leaf blade asymmetric, chartaceous, 14-18.4 $\times$ $5.1-5.9 \mathrm{~cm}$, lanceolate, puberulous on the abaxial venation, hirtellous in the intramarginal venation of the abaxial side, base symmetric, subcordate, apex acute, eucamptodromous venation, 7-12 pairs of secondary veins arcuate, arranged up to apex of the main vein, not prominent on the face adaxial, venation not anastomosed at the margin, margin entire. Spike solitary, erect, 0.9-3.9 cm long, peduncle glabrous. Flower not seen. Fruit not pedicellate, globose, glabrous, pilose at the apex. Selected specimens examined: 4.XII.2014, fr., J.A. Christ 50(VIES); 5.XII.2014, fr., J.A. Christ 60 (VIES); 5.XII.2014, fr., J.A. Christ 61 (VIES); 5.XII.2014, fr., J.A. Christ 62 (VIES); 5.XII.2014, fr., J.A. Christ 63 (VIES); 5.XII.2014, fr., J.A. Christ 64 (VIES); 17.III.2014, fr., T.T. Carrijo et al. 2038 (VIES).

Piper pubsubmarginalum differs from all other species of Piper occurring at MFSP by 
the leaves with subcordate base and fruit pilose at the apex. This species occurs in the states of Bahia, Espírito Santo, Minas Gerais and Rio de Janeiro (BFG 2015). In ES, this species was previously collected on the municipalities Alegre, Cariacica, Marilândia, Santa Leopoldina, Santa Teresa and Vitória (Species Link 2015). In MFSP, $P$. pubisubmarginalum is an understory species. Groups of few individual were observed in areas of valleys, including secondary trails. Immature fruits in December to March.

\section{Piper tuberculatum Jacq.}

Fig. $4 \mathrm{~h}$

Shrub 1.5-2 m tall, branches glabrous with protrusions, internodes ranging $1-4.2 \mathrm{~cm}$. Petiole striate, overlapping the base of the blade, sheath invaginating, $0.3-0.8 \mathrm{~cm}$, glabrous, not overlapping the base of the blade. Leaf blade asymmetric, chartaceous, 2.9-11.3 × 1.8-5.9 $\mathrm{cm}$, oblong, elliptic or lanceolate, glabrous, base asymmetric, round, one size 3-7 $\mathrm{mm}$ shorter at the petiole, apex obtuse or acute, eucamptodromous venation, 6-8 pairs of secondary veins arcuate, arranged up to apex of the main vein, not prominent on the face adaxial, venation anastomosed at the margin, margin entire. Spike solitary, erect, $1.8-5.4 \mathrm{~cm}$ long, peduncle pilose. Flower not pedicellate, bract floral triangular, pubescent fringed, 4-stamens without glands, ovary pilose, stylus inconspicuous, 3-stigma, filiform. Fruit not pedicellate, angulose, glabrous.

Selected specimens examined: 25.II.2013, fl. e fr., T.T. Carrijo et al. 1666 (VIES); 11.XII.2014, fl., J.A. Christ 66 (VIES); 11.XII.2014, fl., J.A. Christ 67 (VIES); 11.XII.2014, fl., J.A. Christ 68 (VIES).

Piper tuberculatum differs from all other species of Piper occurring at MFSP by the combination of branches with protrusions, petioles overlapping the base of the blade, and stigma filiform. This species is widely distributed in Brazil, except for the states of Rio Grande do Sul, Santa Catarina and Sergipe (BFG 2015). In ES, this species was previously collected on the municipalities of Linhares and Mimoso do Sul (Species Link 2015). In the MFSP, P. tuberculatum was observed in open areas near roadsides, often associated with $P$. aduncum. Flowers and fruits in December to February and fruit in February.

\section{Piper umbelatum L.}

Shrub 0,5-1 m tall, branches glabrous, without protrusions, internodes ranging $5-25 \mathrm{~cm}$. Petiole canaliculate, sheath invaginating, 18-22 $\mathrm{cm}$, glabrous, not overlapping the base of the leaf blade. Leaf blade symmetric, chartaceous, 19-25 × 24.2-32.1 cm, cordiform, glabrous, base symmetric, cordate, apex acuminate, campilodromous venation, 7 pairs of secondary veins, arcuate, venation not anastomosed at the margin, margin entire. Spike arranged as umbels 2-4, erect 3.1-9 cm long, peduncle pilose. Flower not pedicellate, bract floral triangular-peltate, pubescent fringed, 2-stamens without glands, ovary glabrous, stylus inconspicuous, 3-stigma, filiform. Fruit not seen.

Selected specimens examined: 13.II.2014, fl., J.A. Christ et al. 20 (VIES).

Piper umbelatum differs from all other species of Piper occurring at MFSP by the leaf blade cordiform and spikes arranged in umbels. The species occurs in all states of Brazil, except in the states of Amapá, Mato Grosso do Sul, Paraíba, Piauí and Rio Grande do Norte (BFG 2015). The species was previously collected in ES on the municipalities of Águia Branca, Cariacica, Colatina, Conceição da Barra, Domingos Martins, Governador Lindenberg, Ibitirama, Itarana, Iúna, Linhares, Nova Venécia, Santa Leopoldina, Santa Maria de Jetibá, Santa Teresa, Serra and Viana (Species Link 2015). In the MFSP, just one individual of this species was observed in an open area near a roadside. Flowers in February.

\section{Piper vicosanum Yunck.}

Fig. 4 i

Shrub 1.5-2 m tall, branches glabrous without protrusions, internodes ranging 3.9-6.4 $\mathrm{cm}$. Petiole canaliculate, sheath invaginating, $0.72-1 \mathrm{~cm}$, glabrous, not overlapping the base of the leaf blade. Leaf blade symmetric, chartaceous, $17.1-24.4 \times 7.8-10.5 \mathrm{~cm}$, elliptic, glabrous, base asymmetric, acute, one size $2-5 \mathrm{~mm}$ shorter at the petiole, apex acute, eucamptodromous venation, 8 pairs of secondary veins, arcuate, arranged up to apex of the main vein, prominent on the face adaxial, venation anastomosed at the margin, margin entire. Spike solitary, erect, $3.1-3.3 \mathrm{~cm}$ long, peduncle glabrous. Flower not seen. Fruit not pedicellate, angulose, glabrous.

Selected specimens examined: 17.XI.2014, fr., J.A. Christ 36(VIES); 17.XI.2014, fr., J.A. Christ 37 (VIES); 17.XI.2014, fr., J.A. Christ 38 (VIES); 17.XI.2014, fr., J.A. Christ 40 (VIES); 4.XII.2014, fr., J.A. Christ 51 (VIES); 4.XII.2014, fr., J.A. Christ 54 (VIES); 4.XII.2014, fr., J.A. Christ 55 (VIES); 4.XII.2014, fr., J.A. Christ 56 (VIES); 4.XII.2014, fr., J.A. Christ 57 (VIES); 4.XII.2014, fr., J.A. Christ 58 (VIES); 11.XII.2014, fr., J.A. Christ 75 (VIES); 11.XII.2014, fr., J.A. Christ 76 (VIES). 
Piper vicosanum resembles $P$. caldense by the petiole canaliculate, eucamptodromous venation and by venation anastomosed at the leaf margin, differing from this species by the leaves with to $17 \mathrm{~cm}$ long and spike erect. This species occurs in the states of Alagoas, Amazonas, Bahia, Distrito Federal, Espírito Santo, Goiás, Maranhão, Mato Grosso, Mato Grosso do Sul, Minas Gerais, Paraná, Pernambuco, Rio de Janeiro, Roraima, and São Paulo (BFG 2015). In ES, the species was previously collected on the municipalities of Águia Branca, Barra de São Francisco, Cachoeiro de Itapemirim, Castelo, João Neiva, Linhares, Marechal Floriano, Santa Teresa, São Mateus, Sooretama, Vila Pavão and Vitória (Species Link 2015). In the MFSP, isolated individuals of $P$. vicosanum were observed in valley areas of the forest understory and near roadsides. Fruits in November to December.

\section{Acknowledgements}

We thank Centro de Ciências Agrárias, Universidade Federal do Espírito Santo for logistical support. To IEMA (Espírito Santo environmental agency) for field support and licenses. FAPES, $\mathrm{CNPq}$, and Capes (Espírito Santo and Brazilian research agencies) for funding (grant number 59152982/2012) and fellowships to M.L. Garbin. FAPES for fellowship to the first author. To Joelcio de Freitas for the illustration. And to Maurício F. Pogian for the map figure.

\section{References}

BFG. 2015. Growing knowledge: an overview of Seed Plant diversity in Brazil. Rodriguésia 66: 1085-1113.

Bardelli, K.C.; Kirizawa, M. \& Sousa, A.V.G. 2008. O gênero Piper L. (Piperaceae) da Mata Atlântica da microbacia do Sítio Cabuçu-Proguaru, Guarulhos, SP. Hoehnea 35: 553-561.

Brummit, R.K. \& Powell, C.E. 1992. Authors of plant names. Royal Botanic Gardens, Kew. 732p.

Carvalho-Okano, R.M. \& Alves, S.A.M. 1998. Piperaceae C. Agardh da estação experimental Mata do Paraíso, Viçosa, MG. Acta Botânica Brasílica 12: 497-513.

Carvalho-Silva, M. \& Guimaraes, E.F. 2009. Piperaceae do Parque Nacional da Serra da Canastra, Minas Gerais. Boletim de Botânica Universidade São Paulo 27: 235-245.

Carvalho-Silva, M.; Guimarães, E.F. \& Medeiros, E.V.S.S. 2013. Flora da Serra do Cipó, Minas Gerais: Piperaceae. Boletim de Botânica Universidade São Paulo 31: 27-40.

Carvalho-Silva, M.; Guimarães, E.F.; Pereira, L.A. \& Sarnaglia Junior, V.B. 2015. Two new species of Piper section Ottonia (Piperaceae) from southeastern Brazil. Phytotaxa 212: 293-299.
Global Plants. [continuously updated]. Piper L. Available at $<$ http://plants.jstor.org/>. Access on 15 November 2013.

Guimarães, E.F. \& Monteiro, D. 2006. Piperaceae na reserva biológica de Poço das Antas, Silva Jardim, Rio de Janeiro. Rodriguésia 57: 567-587.

Guimarães, E.F. \& Valente, M.C. 2001. PiperaceaePiper. In: Flora Ilustrada Catarinense. Herbário Barbosa Rodrigues, Itajaí. 104p.

Guimarães, E.F. \& Carvalho-Silva, M. 2012. Piperaceae In: Wanderley, M.G.W.; Shepherd, G.J.; Melhem, T.S.; Giulietti, A.M. \& Martins, S.E. Flora Fanerogâmica do Estado de São Paulo. Instituto de Botânica, São Paulo. Vol. 7, pp. 263-320.

Hickey, M. \& King, C. 2000. The cambridge illustrated glossary of botanical terms. Cambridge University Press, Cambridge. 334p.

IEMA. Instituto Estadual de Meio Ambiente e Recursos Hídricos. 2014. Available at <http://www. meioambiente.es.gov.br/>. Access on 6 January 2014.

IPEMA. Instituto de Pesquisa da Mata Atlântica. 2011. Áreas prioritárias para conservação da Biodiversidade da Mata Atlântica no estado do Espírito Santo. IPEMA, Vitória. 64p.

Lawrence, G.H.M.; Bucheim, A.F.G.; Daniels, G.S. \& Dolezal, H. (eds.). 1968. Botanico-PeriodicumHuntianum. Hunt Botanical Library, Pittsburgh. $1063 p$.

Medeiros, E.V.S.S. \& Guimaraes, E.F. 2007. Piperaceae do Parque Estadual de Ibitipoca, Minas Gerais, Brasil. Boletim Botânico Universidade de São Paulo 25: 227-252.

Miquel, F.A.W. 1832. Chloranthaceae et Piperaceae. In: Martius, C.F.P. von; Eichler, A.W. \& Urban, I. (eds.). Flora brasiliensis. Lipsiae Frid. Fleischer. Vol. 4, pp. 1-76.

Monteiro, D. \& Guimarães, E.F. 2008. Flora do Parque Nacional do Itatiaia - Brasil: Peperomia (Piperaceae). Rodriguésia 59: 161-195.

Monteiro, D. \& Guimarães, E.F. 2009. Flora do Parque Nacional do Itatiaia - Brasil: Manekia e Piper (Piperaceae). Rodriguésia 60: 999-1024.

Monteiro, D. 2013. Piperaceae em um fragmento de floresta atlântica da Serra da Mantiqueira, Minas Gerais. Rodriguésia 64: 379-398.

Oliveira-Filho, A.T.; Tameirão-Neto, E.; Carvalho, W.A.C.; Werneck, M.; Brina, A.E.; Vidal, C.V.; Rezende, S.C. \& Pereira, J.A.A. 2005. Análise florística do compartimento arbóreo de áreas de Floresta Atlântica sensu lato na região das bacias do Leste (Bahia, Minas Gerais, Espírito Santo e Rio de Janeiro). Rodriguésia 56: 185-235.

Paula, A. 2006. Os estados da Mata Atlântica: Espírito Santo. In: Campanili, M. \& Prochnow, M. Mata Atlântica: uma rede pela floresta. RMA, Brasília. Pp. 114-128.

Peixoto, A.L.; Rosa, M.M.T. da \& Silva, I.M. 
2002. Caracterização da Mata Atlântica. In: Sylvestre, L. da S. \& Rosa, M.M.T. da. Manual metodológico para estudos botânicos na mata Atlântica. EDUR, Seropédica. Pp. 09-23.

Radford, A.E.; Dickinson, W.C.; Massey, J.R. \& Bell C.R. 1974. Vascular plant systematics. Harper \& Row, New York. 891p.

Reflora. 2016. Herbário Virtual. Available at $<$ http:// reflora.jbrj.gov.br/reflora/herbarioVirtual/>. Access on 17 February 2016.

Ribeiro M.C.; Metzger J.P.; Martensen A.C.; Ponzoni F.J. \& Hirota M.M. 2009. The Brazilian Atlantic Forest: how much is left, and how is the remaining forest distributed? Implications for conservation. Biological Conservation 142: 1141-1153.

Species link. 2015. Available at $<$ http://www.splink. org.br/>. Access on 19 March 2015.

Sarnaglia Junior, V.B. \& Guimarães, E.F. 2015. Piper delirioi (Piperaceae), a new species from southeastern Brazil. Phytotaxa 201: 296-300.

Stafleu, F.A. \& Cowan, R.S. 1979. Taxonomic literature. A selective guide to botanical publications and collections with dates, commentaries and types. Vol 2. Bohn, Scheltema \& Holkema, Utrecht. 991p.

Thiers, B. [continuously updated]. Index Herbariorum: A global directory of public herbaria and associated staff. New York Botanical Garden's Virtual Herbarium. Available at $<$ http:// sweetgum.nybg.org/science/ih/>. Access on 19 March 2015.

Tropicos.org. Missouri Botanical Garden. Available at $<$ http://www.tropicos.org $>$. Access on 5 September 2014.

Yuncker, T.G. 1972. The Piperaceae of Brazil I: Piper - Group I, II, III, IV. Hoehnea 2: 19-366.

Yuncker, T.G. 1973. The Piperaceae of Brazil II: Piper - Group V; Ottonia; Pothomorphe; Sarcorhachis. Hoehnea 3: 29-284.

Yuncker, T.G. 1974. The Piperaceae of Brazil III Peperomia; Taxa of uncertain status. Hoehnea 4: 71-413. 